\title{
Study of the process and microbiological quality of Gappal, a fermented food from Burkina Faso based on milk and millet dough
}

\author{
Abel TANKOANO $\#$, , Hagrétou SAWADOGO-LINGANI", Aly SAVADOGO ${ }^{\#}$, Donatien KABORE! and Yves TRAORE \\ "Université Ouaga I Professeur Joseph Ki-Zerbo, UFR/SVT, Laboratoire de Biochimie et Immunologie Appliquée (LaBIA), $03 B$ P 7021 Ouagadougou 03, \\ Burkina Faso \\ 'Centre National de la Recherche Scientifique et Technologique, IRSAT, Département Technologie Alimentaire, 03 BP 7047, Ouagadougou 03, Burkina \\ Faso
}

Accepted 03 Feb 2017, Available online 06 Feb 2017, Vol.5 (Jan/Feb 2017 issue)

\begin{abstract}
Gappal is a traditional fermented food of Burkina Faso's Fulani ethnic group, made with millet dough and milk and traditionally eaten in family. The aim of the present study was to characterize the process of Gappal production, to evaluate the good hygiene practices during production and to assess the microbiological quality of commercialized Gappal. For that, 21 Gappal producers from seven towns of Burkina Faso were surveyed. 106 samples of Gappal commercialized were collected and analysed for $\mathrm{pH}$, titratable acidity, dry matter, total aerobic count, lactic acid bacteria, enterobacteria, yeasts and moulds, Staphylococcus aureus and Bacillus cereus counts. The main operation units of the process were found to be: winnowing, washing, dehulling, pounding and/or milling, milk addition, fermentation, drying and packaging. The microbial values varied from producer to another and $86.8 \%$ of samples were found to have acceptable quality whereas $13.2 \%$ of samples were not conforms to microbiological quality criteria. No sample was satisfactory quality. The fermentation of millet dough mixed to milk gives to Gappal interesting nutritional properties and the drying increase the availability and the preservation duration. However, the presence of germs able to produce toxins in Gappal increases the risk to consumer health.
\end{abstract}

Keywords: Gappal, Process, Fermentation, Quality, Microbiology, Burkina Faso

\section{Introduction}

The millet is one of the main cereals cultivated and consumed in Africa. It constitutes the base of many fermented foods and often mixed with milk (A. Y. Tamime and D. Mc Nulty, 1999; F. Hama et al., 2009; A. Georgala, 2013). Fermentation has been practiced since the early ages and still remains an important aspect of food process that cannot be ignored. With their preservative effects, fermented foods remain popular with people of all generations (P. K. Sarkar and M. R. Nout, 2014). Fermentation is highly involved in a variety of other traditional knowledge and domestic activities. It can make particularly an important contribution to the livelihoods of women, the disabled and landless poor who, with appropriate training and access to inputs, can increase their independence and self-esteem through income generation (E. Marshall and D. Mejia, 2011). This food policy is important in West Africa, where food production and commercialization is women's activities (F. Hama et al., 2009). Traditional fermented foods based on milk and cereals have been produced in many countries. In the Middle East, a dried yoghurt-cereal mixture known as

DOI: https://doi.org/10.14741/ijmcr/v.5.1.18 kishk is a popular product. It is produced in severa countries (Lebanon, Syria, Algeria Egypt, Qatar, Iraq, Iran, Nepal, Greece, Turkey) with different names such as Kushuk, Klila, Keshkeh or Kichk,, Zhum, Kushik, Kashk, Kaskg, Keshk, Churpi, Zurpi, Chum, Trahana, Tarhanocirv, Kapestoes (A. Tamime and T. O'Connor, 1995). In West Africa for instance, Dèguè or Tiacri and Fura are also very popular (F. Hama et al., 2009; J. Owusu-Kwarteng et al., 2012). Another fermented foods based on milk and millet called Gappal, typical to the Fulani ethnic group is increasingly appreciated and consumed by Burkinabe.

But, fermented food based on milk and cereals obtained through a natural and spontaneous fermentation are generally associated to risk for consumers health. So, the microbiological quality of the natural fermented cereal based foods is of great importance because these foods are often given to children and the elderly ( $\mathrm{H}$. Abriouel et al., 2007). Contamination of food by bacteria that form endospores is a widespread problem. For example, a study on phylogenetic relatedness and toxigenic potential of Bacillus cereus isolates from Dèguè and Potopoto revealed the presence of Bacillus anthracis. All the isolates in this study presented lecithinase activity and 104 |Int. J. of Multidisciplinary and Current research, Vol.5 (Jan/Feb 2017) 
beta-hemolytic activity and enterotoxin production was detected in two of the isolates (H. Abriouel et al., 2007). The addition of milk to millet dough can increase the nutritional quality of the product, but it can be a source of pathogenic bacteria. Several studies indicated the presence of pathogenic bacteria like coagulase positive Staphylococcus aureus and other species as Escherichia coli, Salmonella, Enterobacter, Klebsiella pneumoniae and thermotolerant coliforms in dairy products from Burkina Faso. Some bacteria present a high resistance to antibiotics (A. Savadogo et al., 2004; T. S. Bagré et al., 2014; C. A. T. Ouattara et al., 2015; M. Sissao et al., 2015; A. Tankoano et al., 2016). The aim of the present work was to study in detail the process of Gappal in seven towns from Burkina Faso, to establish a general flow diagram of production and then to determine the microbiological quality of commercialized Gappal.

\section{Materials and methods}

\subsection{Investigation on Gappal process}

The main traditional production and commercial sites of Gappal were identified in different provinces of Burkina Faso and production was followed for flow diagrams establishment. The process investigation was done in seven areas such as Dori, Djibo, Sebba, Gorom-Gorom, Fada N'Gourma, Koudougou and Ouagadougou (Figure 1). Twenty one (21) individual producers or groups were investigated. The process study was realized using inquiry form based on: (1) the identification of production site, (2) the raw materials used, (3) the packaging and the distribution channel, (4) the production process and (5) the implementation of good hygienic practices and good manufacturing practices.

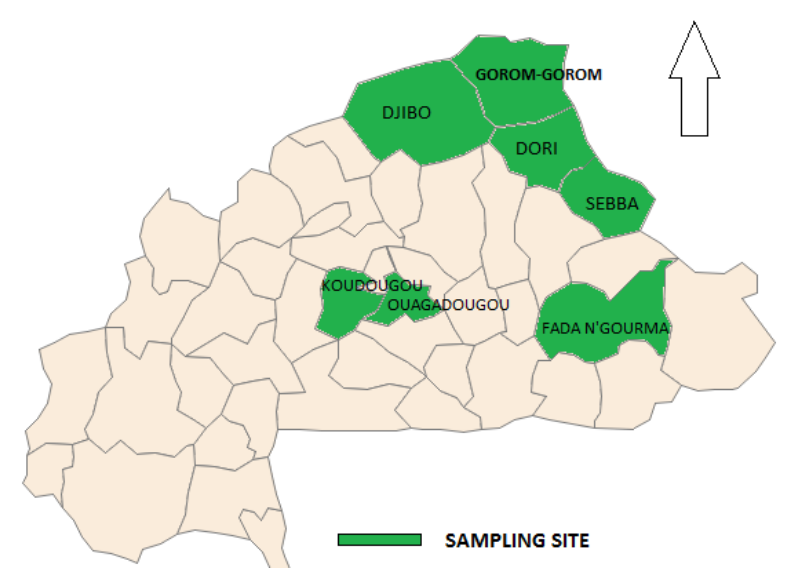

Figure 1: Inquiry site of Gappal production and commercialisation

2.2 Sampling for microbiological and physicochemical analyzes

A total of a hundred and six (106) samples of Gappal (dried and liquid) commercialized from six towns were collected between July and December 2015 for microbiological and physicochemical analyses. The samples of Gappal in the liquid form $(n=46)$ were collected in Koudougou, Fada N'Gourma and Ouagadougou whereas the samples of Gappal in dried form $(n=60)$ were collected in Dori, Djibo, Sebba and Fada $\mathrm{N}^{\prime}$ Gourma. All the samples were transported to the laboratory in cold chain under a temperature of $4^{\circ} \mathrm{C}$ for analyzes.

\subsection{Physicochemical analyzes}

The moisture content was determined by difference of sample weight before and after drying at $105^{\circ} \mathrm{C}$ for $24 \mathrm{~h}$ (NFV03-707, 2000). The $\mathrm{pH}$ values were obtained using electronic pHmeter (CONSORT P901, Belgium) and acidity was determined according to the modified method of Nout et al.; 1989 using phenolphthalein as indicator with $\mathrm{NaOH}$ 0.1N (M. R. Nout et al., 1989).

\subsection{Microbiological analyzes}

In the current study, Total Aerobic Count (TAC), Lactic Acid Bacteria (LAB), Yeasts and Moulds (YM), Enterobacteria, coagulase positive Staphylococcus aureus, and Bacillus cereus were investigated. For TAC, Plate count Agar (Liofilchem, Italy) was used incubated at $30^{\circ} \mathrm{C}$ for $72 \mathrm{~h}$ in aerobic condition (ISO4833, 2003). LAB were counted by cultivation on De Man, Rogosa and Sharpe Agar (Merck, Germany) using container with Generating Sachets (BD Diagnostic, USA) incubated at $37^{\circ} \mathrm{C}$, for $72 \mathrm{~h}$ (ISO15214, 1998) and on M17 Agar (Liofilchem,Italy) incubated aerobically at $30^{\circ} \mathrm{C}$ for $48 \mathrm{~h}$. Yeasts and moulds were counted by cultivation on Sabouraud Chloramphenicol Agar (Liofilchem,Italy) for 4 to 5 days at $25^{\circ} \mathrm{C}$ (ISO7954, 1988). Enterobacteria were counted on Violet Red Bile Glucose Agar (Liofilchem, Italy) for $48 \mathrm{~h}$ at $37^{\circ} \mathrm{C}$. Staphylococcus aureus was determined by surface plating on Baird Parker Agar (Liofilchem,Italy) supplemented with egg yolk-tellurite emulsion $\left(37^{\circ} \mathrm{C}\right.$ for 24-48 h). For the confirmation, coagulase test (Liofilchem, Italy) was realised according to ISO (ISO6888-2, 2003). Concerning Bacillus cereus count, Bacillus cereus Selective Agar (Liofilchem, Italy) supplemented with polymixine $B$ was used, incubated at $37^{\circ} \mathrm{C}$ for $48 \mathrm{~h}$.

\subsection{Statistical analyzes}

All the results were test to Analysis of variance (ANOVA) using XLSTAT 7.5.2 software. Means, Standard deviation and the least significant difference between the means were determined ( $p<0.05)$. Turkey correlations among microbiological and physicochemical values were estimated for all the investigated factors.

\section{Results and discussion}

\subsection{Description of Gappal process}

Gappal is produced with millet and different kinds of milk. The fermentation degree depending on producer and the type of Gappal desired. 
The Fulani ethnic group producer, from Dori, Djibo, Gorom-Gorom and Sebba use raw milk from cow or sour milk for Gappal production. Gappal is their traditional food or beverage and this region is the largest area of breeding in Burkina Faso. For Fulani ethnic group, Gappal production is a cultural and social activity. The other producers from Ouagadougou, Koudougou and Fada N'Gourma, used generally powder milk for Gappal production. In this case, Gappal production is most a commercial activity and powder milk is most available and most benefit for them. A combined fermentation of milk and millet dough could increase the nutritional and sensorial quality of Gappal. The main operation units of Gappal process were: winnowing, washing, dehulling, pounding and/or milling (Figure 2, 3 and 4). For dried Gappal a operation unit of drying combined to fermentation is added. During this operation unit, the mixture of millet dough and milk was fermented and millet dough quantity was increased compared to liquid Gappal. Figure 2 presents the traditional process; Figure 3 and Figure 4 present the commercial liquid and dried Gappal process.

Winnowing: It is performed with metal sieves or calabashes to eliminate hulls, insects, and dust.

Washing: The grains of millet were washed thrice with potable water to eliminate all impurities.

Dehulling: This operation unit is not necessary. It consists to separate millet grain from the seed heads. The resulting Gappal is whiter and limpid

Drying: The grains were sun dried for few minutes after the operation unit of washing.

Milling: This operation unit consists of transforming the millet grains obtained in the previous step into flour in popular milling units. Producers added ingredients such as ginger and baobab pulp before milling whereas mint, cloves or artificial aroma were added after milling.

Sieving: the flour was sieved with metal sieve.

Pounding and mixing: Millet grains were pounded into flour and semolina with traditional mortar. Gappal containing semolina is particularly appreciated by some consumers. This operation unit is very important in Gappal production. For dried Gappal, flour is mixed to milk and the mixture is pounded. For liquid Gappal, flour is pounded properly before mixing with milk or yogurt. Pounding eliminate the fresh taste of flour and promote a better mixing with milk. The ratio of milk to dough used in liquid Gappal production is usually $4: 1$ or $5: 1$. For dried Gappal this ratio is usually $1: 4$ or $1: 5$

Drying and fermentation: In the dried Gappal process, the mixture was sun dried during three to five days. The first day, Gappal was dried in the room then exposed to sun covered with a thin fabric.

Storage: Liquid Gappal was packaged in cans and stored in a freezer or refrigerator. Dried Gappal is packaged in plastics bags and store at ambient temperature.

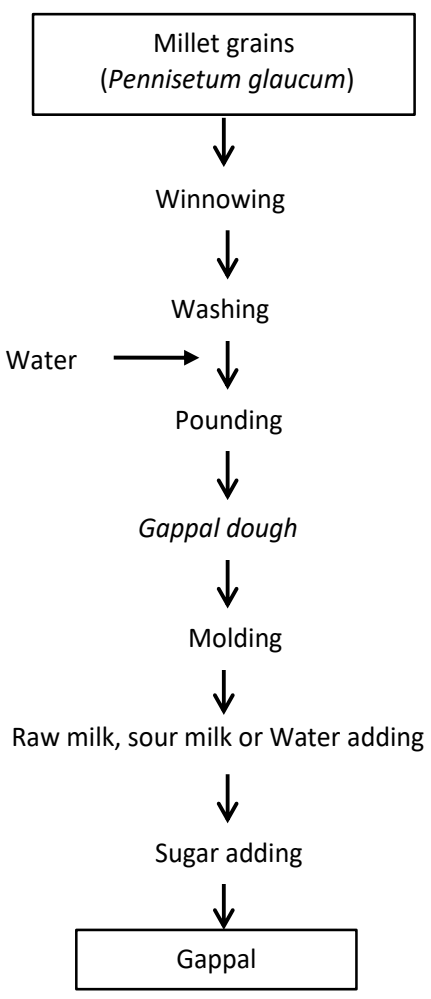

Figure 2: Traditional process of Gappal

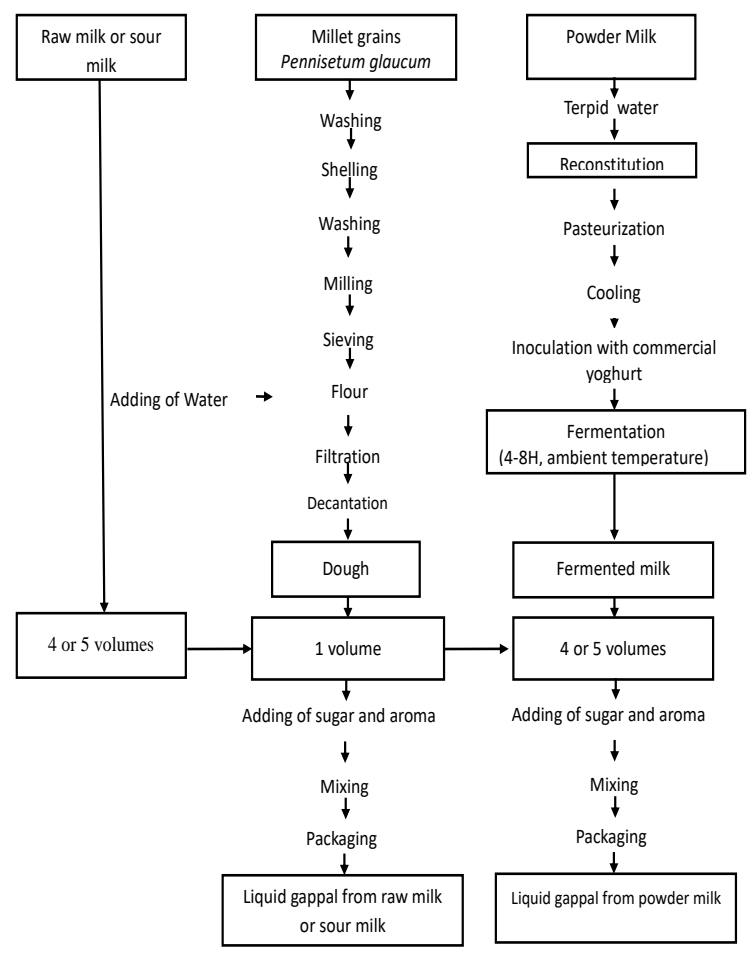

Figure 3: Process of commercial liquid Gappal 


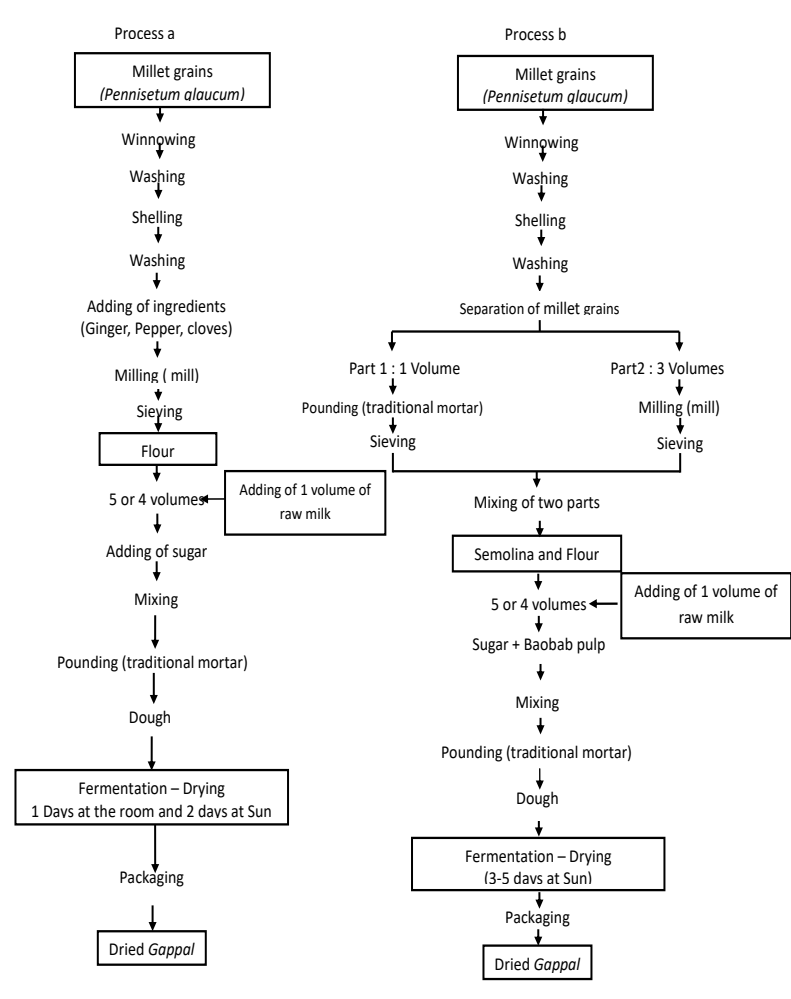

Figure 4: Process of commercial dried Gappal

\subsection{Attributes and traditional uses of Gappal}

Traditionally the preparation of Gappal in Burkina Faso remains in Fulani ethnic household for family consumption or foreigner welcome drink. Women prepare Gappal dough and store it in their house for eventual foreigner. According to traditional perceptions, Gappal consumption increase milk secretion, so it is also served to new mothers after the birth. In this case, there is no dehulling of the millet grains and Gappal is produced directly for mother's consumption. With the increasing of dairy products demand, in order to transport and conserve during a long time, Gappal producers introduce sun drying after increasing of the quantity of millet dough compared to milk, madding the dried Gappal.
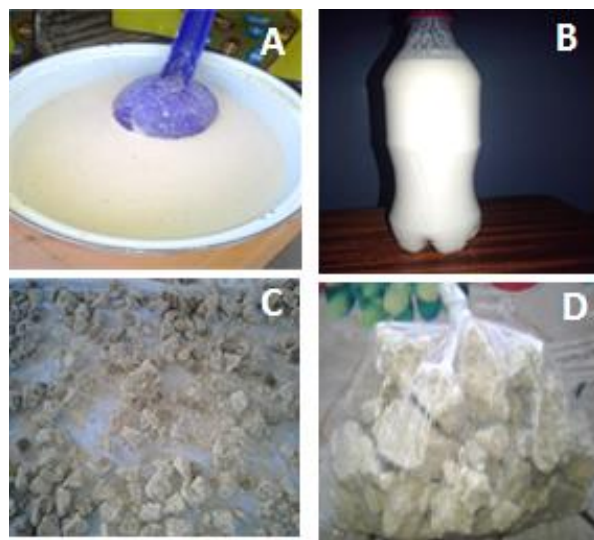

(a) Traditional Gappal, (b) Commercial liquid Gappal, (c) Gappal drying; (d) Commercial dried Gappal

Figure 5: Different forms of Gappal produced in Burkina Faso

\subsection{Production, distribution channel and respect of good} hygienic and good manufacturing practices

Dried Gappal and Liquid Gappal are produced from millet dough mixed with milk. Liquid Gappal was packaged in cans and dried Gappal was packaged in plastic bags. $85 \%$ of producers disturbed to kiosks, shops and supermarkets but $48 \%$ of Gappal producers are illiterates and $79 \%$ have never been trained for dairy food production. $42 \%$ of Gappal producers made only liquid Gappal and some producers especially those from Ouagadougou, Koudougou and Fada N'Gourma don't know dried Gappal process. For the producers from these towns, Gappal production is most a commercial activity and powder milk is most available and most benefit for them. In these towns, Gappal is produced with powder milk unlike Dori, Djibo, Sebba and Gorom-Gorom towns where it is produced with raw milk from cows or sour milk; also, Gappal production is a cultural and social activity for these producers. Curd milk or commercial yoghurt were used as lactic ferment by all producers. Liquid Gappal fermentation is stopped after the production by conservation in a freezer. For dried Gappal, the mixture of milk and millet dough was dried during three to five days. The first day, Gappal was dried in the room at ambient temperature and it is exposed in sun covered with a thin fabric. Only one producer used solar dryer. $89 \%$ of producer used correctly soap during Gappal production for hands and materials washing, but only $11 \%$ of producers had appropriate clothing with apron. In these groups, members wchich were trained on raw milk quality control used lactodensimeter, pHmeter or resazurine. Despite the used of soap during Gappal production, some problems like inadequate local and equipments, the presence of animals in some production sites were unconformities to good hygiene recommendations during food production.

\subsection{Physicochemical and microbiological results}

Table 1 presents the physicochemical parameters of Gappal such as $\mathrm{pH}$, titratable acidity, moisture and dry matter. The $\mathrm{pH}$ was $4.31 \pm 0.28$ for liquid Gappal and $4.74 \pm 0.35$ for dried Gappal. The titratable acidity was $1.31 \pm 0.23$ percent of lactic acid for liquid Gappal against $0.87 \pm 0.05$ percent lactic acid for dried Gappal with statistical difference between liquid and dried Gappal for these parameters. These values are similar to those obtained in other cereal-dairy based foods like Dèguè Kashk-e Zard and Tarkhineh. In fact the $\mathrm{pH}$ of millet dèguè varied between 4.22 and 4.49 and acidity varied between 0.57 and $1.35 \%$ of acid lactic (F. Hama et al., 2009; C. C. Tchekessi et al., 2014). Kashk-e Zard and Tarkhineh, cereal-dairy based fermented foods from Iran, had low $\mathrm{pH}, 4.31$ and 4.91 respectively (Z. Mashak et al., 2014). A combined fermentation of milk and millet dough could increase the nutritional and sensorial quality of Gappal. The few concentration of millet dough in liquid Gappal gives it a similar appearance to yoghurt. 
Table 1: Physicochemical parameters of Gappal

\begin{tabular}{|c|c|c|c|c|}
\hline \multirow{2}{*}{ Sampling site } & $\mathrm{pH}$ & Acidity (\%) & Moisture (\%) & Dried matter (\%) \\
\hline & \multicolumn{4}{|l|}{ Liquid Gappal } \\
\hline Fada $(n=15)$ & $4.30 \pm 0.10^{\mathrm{a}}$ & $1.31 \pm 0.25^{\mathrm{a}}$ & $74.63 \pm 2.17^{a}$ & $25.37 \pm 2.17^{\mathrm{a}}$ \\
\hline Koudougou $(n=15)$ & $4.22 \pm 0.23^{\mathrm{a}}$ & $1.40 \pm 0.23^{a}$ & $69.25 \pm 8 . .^{46 a b}$ & $30.75 \pm 8.46^{\mathrm{ab}}$ \\
\hline Ouagadougou $(n=16)$ & $4.44 \pm 0.41^{a}$ & $1.19 \pm 0.03^{a}$ & $64.31 \pm 1.57^{b}$ & $35.69 \pm 1.57^{b}$ \\
\hline \multirow[t]{2}{*}{ Mean } & $4.31 \pm 0.28$ & $1.31 \pm 0.23$ & $69.52 \pm 6.83$ & $30.48 \pm 6.83$ \\
\hline & \multicolumn{4}{|l|}{ Dried Gappal } \\
\hline Djibo $(n=15)$ & $4.50 \pm 0.14^{c}$ & $1.02 \pm 0.04^{a}$ & $9.74 \pm 4.12^{a}$ & $90.26 \pm 4.12^{\mathrm{a}}$ \\
\hline Dori $(n=20)$ & $4.66 \pm 0.11^{b}$ & $0.93 \pm 0.05^{\mathrm{a}}$ & $6.97 \pm 0.28^{b}$ & $93.03 \pm 0.28^{b}$ \\
\hline Fada $(n=20)$ & $5.36 \pm 0.01^{a}$ & $0.79 \pm 0.06^{a}$ & $6.17 \pm 0.06^{b}$ & $93.83 \pm 0.06^{b}$ \\
\hline Sebba $(n=5)$ & $5.35 \pm 0.01^{a}$ & $0.75 \pm 0.03^{a}$ & $6.10 \pm 0.13^{b}$ & $93.90 \pm 0.11^{b}$ \\
\hline Mean & $4.74 \pm 0.35$ & $0.87 \pm 0.05$ & $7.89 \pm 2.97$ & $92.11 \pm 2.97$ \\
\hline
\end{tabular}

The same letter $(a, b, c)$ in the same column indicated no statistical difference $(p \geq 0.05)$ between the values obtained in the different towns for the same type of Gappal.

Liquid Gappal is more fermented than dried Gappal and the $\mathrm{pH}$ of liquid Gappal is similar to those of normal yoghurt $(\mathrm{ph} \leq 4.5)$ and indicates a good fermentation condition. At these values of $\mathrm{pH}$ and acidity, the development of many pathogens like enterobacteria and Staphylococcus aureus is reduced and food safety preserved (A. Savadogo et al., 2004). But the addition of millet flour during the production of Gappal increase the dried matter. Dried Gappal contains more dry matter $(92.11 \pm 2.97 \%$ of dry matter) than Liquid Gappal $(30.48 \pm 6.83 \%)$. The dry matter of dried Gappal is similar to those obtained for Kashk-e Zard and Tarkhineh with respectively $95.08 \%$ and $96.96 \%$ (Z. Mashak et al., 2014). Table 3 presents the microbiological quality of commercial liquid Gappal and dried Gappal of samples from Dori, Djibo, Sebba, Koudougou, Ouagadougou and Fada N'Gourma. $82.6 \%$ of liquid Gappal samples were found to have an acceptable quality against $90.0 \%$ of dried Gappal samples using Enterobacteria, coagulase positive Staphylococcus aureus and Bacillus cereus criteria. Globally (Table 2), $86.8 \%$ of the total samples were acceptable quality. Only $13.2 \%$ of total samples were not satisfactory quality. Coagulase positive Staphylococcus aureus, other coagulase positives staphylococci and Enterobacteria are the mains microorganisms responsible of the bad microbiological quality of Gappal. However, the presence of coagulase positive Staphylococcus aureus (table 2 and table 3) in high concentration is potentially injurious to health and / or unfit for human consumption (HPA, 2009). In fact, figure 5 presents the mean values for Total Aerobic Count (TAC), Lactic Acid Bacteria (LAB), Yeasts and Moulds, Enterobacteria, coagulase positive Staphylococcus aureus and Bacillus cereus in liquid Gappal and dried Gappal. The values deviate to mean values with standard deviation frequently superior to mean, indicating that microbiological count change from a producer to another and also from a town to another. This observation was confirmed by statistical analyzes using ANOVA test. The mean value for TAC was $3.3 \times 10^{8} \pm 4.5 \times 10^{8} \mathrm{cfu} / \mathrm{mL}$ for liquid Gappal and $2.0 \times 10^{6} \pm 4.5 \times 10^{6} \mathrm{cfu} / \mathrm{g}$ for dried Gappal. These values are similar to $7.31 \pm 0.19 \log 10 \mathrm{cfu} / \mathrm{g}$ of tota aerobic count obtained by Tchékessi in millet Dèguè from controlled production (C. Tchekessi et al., 2014). The mean LAB was $1.7 \times 10^{8} \pm 3.5 \times 10^{8} \mathrm{cfu} / \mathrm{mL}$ for liquid Gappal and $1.8 \times 10^{5} \pm 3.1 \times 10^{5} \mathrm{cfu} / \mathrm{g}$ for dried Gappal. LAB on M17 Agar were $2.8 \times 10^{7} \pm 1.0 \times 10^{8} \mathrm{cfu} / \mathrm{mL}$ for liquid Gappal and $1.0 \times 10^{5} \pm 3.9 \times 10^{5} \mathrm{cfu} / \mathrm{g}$ in dried Gappal. The content of yeasts and moulds was $1.9 \times 10^{4} \pm 3.2 \times 10^{4} \mathrm{cfu} / \mathrm{mL}$ in liquid Gappal and $2.3 \times 10^{4} \pm 6.0 \times 10^{4} \mathrm{cfu} / \mathrm{g}$ in dried Gappal.

Lactic acid bacteria, Bacillus cereus, yeasts and moulds count reveals that the dominant micro-flora of Gappal is composed of lactic acid bacteria, Bacillus and yeasts and moulds. The same conclusions were obtained for Dèguè and kishsk where, the number of lactic acid bacteria, yeasts and moulds increased during the fermentation ( $A$ Y. Tamime and D. Mc Nulty, 1999; F. Hama et al., 2009; E. Marshall and D. Mejia, 2011; Z. Mashak et al., 2014). Enterobacteria were $2.0 \times 10^{4} \pm 6.4 \times 10^{4} \mathrm{cfu} / \mathrm{mL}$ for liquid Gappal and $2.5 \times 10^{4} \pm 1.5 \times 10^{5} \mathrm{cfu} / \mathrm{g}$ for dried Gappal. The concentrations of coagulase positive Staphylococcus aureus were $3.9 \times 10^{2} \pm 2.0 \times 10^{3} \mathrm{cfu} / \mathrm{mL}$ for liquid Gappal and $2.0 \times 10^{4} \pm 5.7 \times 10^{4} \mathrm{cfu} / \mathrm{g}$ for dried Gappal and Bacillus cereus were $4.5 \times 10^{6} \pm 1.1 \times 10^{7} \mathrm{cfu} / \mathrm{mL}$ for liquid Gappal against $4.8 \times 10^{4} \pm 1.3 \times 10^{5} \mathrm{cfu} / \mathrm{g}$ for dried Gappal. The investigation of Tamine on Kishk indicated that $B$. cereus strains that may produce toxins could be the major bacteriological risk associated with this product and Zinzerdof's study on Ivorian Dèguè indicated that the enterotoxins of $S$. aureus were detected in $4.1 \%$ of the Dégué from supermarkets against $29.6 \%$ of the Dégué collected from the markets (A. Y. Tamime and D. Mc Nulty, 1999; N. Zinzendorf et al., 2009). The low moisture contained of dried Gappal should permit a long storage at ambient condition comparatively to liquid Gappal. Enterotoxigenic strains need to grow at levels superior to $10^{5} \mathrm{cfu} / \mathrm{g}$ before detectable toxin production which is influenced by parameters such as temperature, $\mathrm{pH}$, water activity, redox potential. Previous studies indicated the presence of Staphylococcus aureus in milk and dairy product from Burkina Faso (T. S. Bagré et al., 2014; A. Tankoano et al., 2016). 
Table 2: Microbiological criteria (cfu/g or $\mathrm{cfu} / \mathrm{mL}$ )

\begin{tabular}{cccc}
\hline & Enterobacteria & S. aureus & B. cereus \\
\cline { 2 - 4 } Unsatisfactory & $>10^{4}$ & $>10^{4}$ & $>10^{5}$ \\
Acceptable & $10^{2} \leq \mathrm{N} \leq 10^{5}$ & $20 \leq \mathrm{N} \leq 10^{4}$ & $10^{3} \leq \mathrm{N} \leq 10^{5}$ \\
Satisfactory & $<10^{2}$ & $<20$ & $<10^{3}$ \\
\hline
\end{tabular}

According to Health Protection Agency. Guidelines for Assessing the Microbiological Safety of Ready-to-Eat Foods. London: Health Protection Agency, November 2009

Table 3: Microbiological quality of Gappal according to criteria

\begin{tabular}{|c|c|c|c|c|c|}
\hline \multirow[b]{2}{*}{ Nature of samples } & \multirow[b]{2}{*}{ Conformity } & \multicolumn{2}{|c|}{ Prevalence of pathogenic microorganism } & \multirow[b]{2}{*}{ B. cereus } & \multirow[b]{2}{*}{$\begin{array}{l}\text { Global } \\
\text { Interpretation }\end{array}$} \\
\hline & & Enterobacteria & S. aureus & & \\
\hline \multirow{3}{*}{ Liquid Gappal } & Unsatisfactory & $8 / 46(17.4 \%)$ & $1 / 46(2.2 \%)$ & $0 / 46(0 \%)$ & $8 / 46(17.4 \%)$ \\
\hline & Acceptable & $17 / 46(37.0 \%)$ & $23 / 46(50 \%)$ & $43 / 46(93.5 \%)$ & $38 / 46(82.6 \%)$ \\
\hline & Satisfactory & $21 / 46(45.7 \%)$ & $22 / 46(47.8 \%)$ & $3 / 46(6.5 \%)$ & $0 / 46(0 \%)$ \\
\hline \multirow{3}{*}{ Dried Gappal } & Unsatisfactory & $5 / 60(8.3 \%)$ & $9 / 60(15.0 \%)$ & $0 / 60(0 \%)$ & $6 / 60(10.0 \%)$ \\
\hline & Acceptable & $6 / 60(10.0 \%)$ & $46 / 60(76.7 \%)$ & $9 / 60(15.0 \%)$ & $54 / 60(90.0 \%)$ \\
\hline & Satisfactory & $49 / 60(81.7 \%)$ & $5 / 60(8.3 \%)$ & $51 / 60(85.0 \%)$ & $0 / 60(0 \%)$ \\
\hline \multirow{3}{*}{ Total samples } & Unsatisfactory & $13 / 106(12.3 \%)$ & $10 / 106(9.4 \%)$ & $0 / 106(0 \%)$ & $14 / 106(13.2 \%)$ \\
\hline & Acceptable & $24 / 106$ (22.6\%) & $67 / 106(63.2 \%)$ & $57 / 74(53.8 \%)$ & $92 / 106(86.8 \%)$ \\
\hline & Satisfactory & $69 / 106$ (65.1\%) & $29 / 106(27.4 \%)$ & 49/74(66.2\%) & $0 / 106(0 \%)$ \\
\hline
\end{tabular}

Table 4: Microbiological count of commercial liquid Gappal and dried Gappal by sampling site

\begin{tabular}{|c|c|c|c|c|c|c|c|}
\hline Sampling site & TAC & LAB on MRS & LAB on M17 & Yeast & Enterobacteria & S. aureus & B. cereus \\
\hline & \multicolumn{7}{|c|}{ Liquid Gappal } \\
\hline Fada $(n=15)$ & $2.4 \times 10^{8} \pm 2.9 \times 10^{8 b}$ & $7.3 \times 10^{5} \pm 1.0 \times 10^{6 b}$ & $8.7 \times 10^{5} \pm 2.8 \times 10^{6 a}$ & $4.8 \times 10^{3} \pm 9.2 \times 10^{3 b}$ & $2.9 \times 10^{2} \pm 6.4 \times 10^{2 a}$ & $2.5 \times 10^{1} \pm 2.8 \times 10^{1 a}$ & $1.9 \times 10^{4} \pm 3.0 \times 10^{4 b}$ \\
\hline Koudougou(n=15) & $1.0 \times 10^{7} \pm 9.8 \times 10^{6 \mathrm{~b}}$ & $1.3 \times 10^{7} \pm 1.4 \times 10^{7 b}$ & $2.5 \times 10^{4} \pm 1.1 \times 10^{4 a b}$ & $1.5 \times 10^{4} \pm 1.7 \times 10^{4 a b}$ & $4.8 \times 10^{4} \pm 9.3 \times 10^{4 a}$ & $9.0 \times 10^{2} \pm 3.1 \times 10^{3 a}$ & $1.8 \times 10^{4} \pm 1.5 \times 10^{4 \mathrm{~b}}$ \\
\hline Ouagadougou $(n=16)$ & $9.1 \times 10^{8} \pm 3.4 \times 10^{8 b}$ & $5.9 \times 10^{8} \pm 4.6 \times 10^{8 a}$ & $1.0 \times 10^{8} \pm 1.8 \times 10^{8 \mathrm{~b}}$ & $4.1 \times 10^{4} \pm 5.1 \times 10^{4 b}$ & $6.2 \times 10^{1} \pm 9.5 \times 10^{1 \mathrm{a}}$ & $3.7 \times 10^{1} \pm 1.1 \times 10^{2 a}$ & $1.6 \times 10^{7} \pm 1.6 \times 10^{7 a}$ \\
\hline \multirow[t]{2}{*}{ Total samples } & $3.3 \times 10^{8} \pm 4.5 \times 10^{8}$ & $1.7 \times 10^{8} \pm 3.5 \times 10^{8}$ & $2.8 \times 10^{7} \pm 1.0 \times 10^{8}$ & $1.9 \times 10^{4} \pm 3.2 \times 10^{4}$ & $2.0 \times 10^{4} \pm 6.4 \times 10^{4}$ & $3.9 \times 10^{2} \pm 2.0 \times 10^{3}$ & $4.5 \times 10^{6} \pm 1$ \\
\hline & \multicolumn{7}{|c|}{ Dried Gappal } \\
\hline Djibo ( & $0^{4} \pm 1$ & $10^{5 \mathrm{a}}$ & U & $2.2 \times 10^{3} \pm 3.2 \times 10^{3 a}$ & $0^{1 a}$ & $\times 10^{3 b}$ & $1.3 \times 10^{2} \pm 1$ \\
\hline Dori $(n=20)$ & $7.5 \times 10^{5} \pm 1.5 \times 10^{6 \mathrm{~b}}$ & $3.5 \times 10^{4} \pm 6.3 \times 10^{4 \mathrm{~b}}$ & $2.3 \times 10^{4} \pm 3.4 \times 10^{4 \mathrm{~b}}$ & $5.0 \times 10^{4} \pm 9.1 \times 10^{4 a}$ & $2.6 \times 10^{1} \pm 7.9 \times 10^{1 \mathrm{a}}$ & $1.3 \times 10^{3} \pm 2.3 \times 10^{3 \mathrm{~b}}$ & $6.2 \times 10^{2} \pm 1.5 \times 10^{3 \mathrm{~b}}$ \\
\hline $\operatorname{Fada}(n=20)$ & $1.3 \times 10^{7} \pm 4.6 \times 10^{6 \mathrm{a}}$ & $2.4 \times 10^{5} \pm 1.2 \times 10^{5 a b}$ & $6.8 \times 10^{5} \pm 9.6 \times 10^{5 a}$ & $1.3 \times 10^{4} \pm 4.2 \times 10^{3 a}$ & $1.9 \times 10^{5} \pm 4.1 \times 10^{5 \mathrm{a}}$ & $1.4 \times 10^{5} \pm 9.5 \times 10^{4 a}$ & $3.6 \times 10^{5} \pm 1.2 \times 10^{5 a}$ \\
\hline Sebba $(n=05)$ & $6.2 \times 10^{4} \pm 2.4 \times 10^{4 \mathrm{~b}}$ & $1.0 \times 10^{4} \pm 3.6 \times 10^{3 b}$ & $1.2 \times 10^{4} \pm 1.3 \times 10^{4 \mathrm{~b}}$ & $1.0 \times 10^{4} \pm 6.7 \times 10^{3 \mathrm{a}}$ & $0 \pm 0$ a & $3.9 \times 10^{3} \pm 5.3 \times 10^{3 \mathrm{~b}}$ & $5.0 \times 10^{1} \pm 4.4 \times 10^{1 b}$ \\
\hline Total samples & $2.0 \times 10^{6} \pm 4.5 \times 10^{6}$ & $1.8 \times 10^{5} \pm 3.1 \times 10^{5}$ & $1.0 \times 10^{5} \pm 3.9 \times 10^{5}$ & $2.3 \times 10^{4} \pm 6.0 \times 10^{4}$ & $2.5 \times 10^{4} \pm 1.5 \times 10^{5}$ & $2.0 \times 10^{4} \pm 5.7 \times 10^{4}$ & $4.8 \times 10^{4} \pm 1.3 \times 10^{5}$ \\
\hline
\end{tabular}

The same letter $(a, b, c)$ in the same column indicated no statistical difference $(p \geq 0.05)$ between the values obtained in the different towns for the same type of Gappal.

Once formed, toxins are extremely difficult to eliminate from foods and the absence of cooking in Gappal processes is an important factor. The microbiological values obtained although inferior to limits are generally beside to them. This observation is applicable to Bacillus cereus. In fact, all the samples are acceptable according Bacillus cereus criteria but large numbers of Bacillus cereus are capable to cause illness either by releasing toxin into the food prior to consumption or by producing a different toxin or toxins in the gut after eating the food (HPA, 2009). The ambient temperature of Burkina Faso can be suitable for Bacillus cereus diarrhoeal toxin production. Lactic acid bacteria are essential for metabolites production, mycotoxin degradation and enzymes production. Combined to yeast, their probiotic effects are actually confirmed and used to probiotic food production (E. Marshall and D. Mejia, 2011; A. Georgala, 2013; C. Tchekessi et al., 2014). The lack of cooking step during the Gappal process conserve the nutrients contained in milk and millet dough and a good fermentation could reduce anti-nutritional factor like phytates and tannins contained in millet grains (C. Mouquet-Rivier et al., 2008; O. Taiwo, 2009; P. Chelule et al., 2010; A. A. Soro-Yao et al., 2014) and increase the nutritional and sensorial quality of Gappal.

\section{Conclusion}

Gappal is a fermented food based on milk and millet dough present like beverage (liquid) or food (dried). It consumption in major towns of Burkina is increasingly significant. The introduction of drying for dried Gappal production increase it conservation and gives opportunities for it technology improvement using starter with interesting process properties. A good improvement of this product should permit a semi-industrial and industrial production. Microbiological quality of commercial Gappal is acceptable but varied from producer to another. However, spores forming bacteria counted and their probable toxin production reveal a risk for consumer. It is necessary to evaluate nutritional quality of this product and train producer for personal hygiene improved, good hygiene practices and good manufacturing practices.

\section{Acknowledgements}

The authors would like to acknowledge the Gappal producers associations for their contribution. 


\section{References}

[1]. Tamime, A.Y. and D. Mc Nulty, Kishk-a dried fermented milk/cereal mixture. 4. Microbiological quality. Le Lait, 1999. 79(4): p. 449-456.

[2]. Hama, F., et al., Biochemical, microbial and processing study of Dèguè a fermented food (from pearl millet dough) from Burkina Faso. Pakistan Journal of Nutrition, 2009. 8(6): p. 759-764.

[3]. Georgala, A., The Nutritional Value of Two Fermented Milk/Cereal Foods Named Greek Trahanas and Turkish Tarhana: A Review. Journal of Nutritional Disorders \& Therapy, 2013. Special Issue 2013: p. S11: 002.

[4]. Sarkar, P.K. and M.R. Nout, Handbook of Indigenous Foods Involving Alkaline Fermentation. Fermented foods and beverages series, ed. M.J.R.N.a.P.K. Sarkar. 2014: CRC Press. 565p. 565.

[5]. Marshall, E. and D. Mejia, Traditionnal fermented food and beverages for improve livelihoods, FAO, Editor. 2011, FAO: Rome

[6]. Tamime, A. and T. O'Connor, Kishk-a dried fermented milk/cereal mixture. International Dairy Journal, 1995. 5(2): p. 109-128.

[7]. Owusu-Kwarteng, J., et al., Identification of lactic acid bacteria isolated during traditional fura processing in Ghana. Food microbiology, 2012. 32(1): p. 72-78.

[8]. Abriouel, H., et al., Differentiation and characterization by molecular techniques of Bacillus cereus group isolates from poto poto and degue, two traditional cereal-based fermented foods of Burkina Faso and Republic of Congo. Journal of Food Protection 2007. 70(5): p. 1165-1173.

[9]. Savadogo, A., et al., Microorganisms involved in Fulani traditional fermented milk in Burkina Faso. International Journal of Biosciences, 2004. 3(2): p. 134-139.

[10].Sissao, M., V. Millogo, and G.A. Ouedraogo, Composition chimique et qualité bactériologique des laits crus et pasteurisés au Burkina Faso. Afrique Science: Revue Internationale des Sciences et Technologie, 2015. 11(1): p. 142-154.

[11]. Ouattara, C.A.T., et al., Isolation and identification of lactic acid and non-acid lactic bacteria from dgu of Western Africa traditional fermented millet-based food. African Journal of Microbiology Research, 2015. 9(36): p. 20012005.

[12]. Bagré, T.S., et al., Antibiotic susceptibility of Escherichia coli and Salmonella strains isolated from raw and curds milk consumed in Ouagadougou and Ziniaré, Burkina Faso. African Journal of Microbiology Research, 2014. 8: p. 10121016.

[13]. Tankoano, A., et al., Evaluation of microbiological quality of raw milk, sour milk and artisanal yoghurt from Ouagadougou, Burkina Faso. African Journal of Microbiology Research, 2016. 10(16): p. 535-541.

[14]. NFV03-707, Céréales et produits céréaliers - Détermination de la teneur en eau - Méthodes de référence pratique. 2000.
[15]. Nout, M.R., F. Rombouts, and A. Havelaar, Effect of accelerated natural lactic fermentation of infant good ingredients on some pathogenic microorganisms. International Journal of Food Microbiology, 1989. 8(4): p. 351-361.

[16].ISO4833, International standard. Microbiology of food. Horizontal method for the enumeration of the microorganisms; technique of counting of the colonies with $30^{\circ} \mathrm{C}$. 2003: p. 9p.

[17]. ISO15214, Microbiology of food - horizontal Method for the enumeration of the mesophilic lactic acid bacteria Technical by counting of the colony at $30^{\circ} \mathrm{C}$. French standard 1998: p. 7p.

[18]. ISO7954, Microbiology - General guidance for enumeration of yeasts and moulds - Colony count technique at $25{ }^{\circ} \mathrm{C}$. 1988. French standard: p. 4 p.

[19].ISO6888-2, Microbiology of food. Horizontal methods for the enumeration of the staphylococcal with coagulase positive (Staphylococcus aureus and other species). Part 2: technical using agar medium with the rabbit plasma and the fibrinogn. French standard, 2003: p. 7p.

[20].Tchekessi, C.C., et al., Physico-chemical and sensory characterizations of three types of" dèguè", a local fermented drink made from milk in Benin. International Journal of Biosciences (IJB), 2014. 5(3): p. 36-43.

[21]. Mashak, Z., et al., Chemical and microbial properties of two Iranian traditional fermented cereal-dairy based foods: Kashk-e Zard and Tarkhineh. International Journal of Biosciences, 2014. 4(12): p. 124-33.

[22]. HPA, Health Protection Agency. Guidelines for Assessing the Microbiological Safety of Ready-to-Eat Foods. . London Health Protection Agency, 2009: p. 34p.

[23].Tchekessi, C., et al., Production and microbiological evaluation of three types of" Dèguè", a local fermented drink made from milk in Benin. International Journal of Multidisciplinary and Current Research, 2014. 2: p. 714720.

[24].Zinzendorf, N., et al., Prévalence de Staphylococcus aureus enterotoxinogène dans le "dégué» vendu dans trois communes de la ville d'Abidjan, Côte d'Ivoire. MHA, 2009. 21(62): p. 41-44.

[25].Taiwo, O., Physical and nutritive properties of fermented cereal foods. African Journal of Food Science, 2009. 3(2): $p$. 023-027.

[26]. Chelule, P., M. Mokoena, and N. Gqaleni, Advantages of traditional lactic acid bacteria fermentation of food in Africa Current Research, Technology and Education Topics in Applied Microbiology and Microbial Biotechnology 2010: p. 1160-1167.

[27]. Mouquet-Rivier, C., et al., Consumption pattern, biochemical composition and nutritional value of fermented pearl millet gruels in Burkina Faso. International journal of food sciences and nutrition, 2008. 59(7-8): p. 716-729.

[28]. Soro-Yao, A.A., et al., The Use of Lactic Acid Bacteria Starter Cultures during the Processing of Fermented Cereal-based Foods in West Africa: A Review Tropical Life Sciences Research, 2014. 25(2): p. 81-100. 